\title{
Pengaruh Dukungan Supervisor Terhadap Work Family Conflict
}

\author{
Wike $^{1 *}$, Endah Setyowati ${ }^{2}$, Tri Wulida Afrianty ${ }^{3}$, Tulus Sabrina ${ }^{4}$ \\ 1 Jurusan Administrasi Publik, Fakultas IImu Administrasi, Universitas Brawijaya \\ 2Jurusan Administrasi Publik, Fakultas IImu Administrasi, Universitas Brawijaya \\ 3Jurusan Administrasi Bisnis, Fakultas Ilmu Administrasi, Universitas Brawijaya
}

\begin{abstract}
Abstrak
Penelitian empiris di bidang work family conflict (konflik antara kerja dan keluarga) menunjukkan bahwa work family conflict memiliki dampak yang negatif terhadap individu, keluarga dan organisasi. Penelitian mengenai dampak dukungan organisasi (work life balance policies dan FSSB) terhadap karyawan sampai saat ini didominasi oleh penelitian di konteks western countries. Disebabkan adanya perbedaan sosial dan kultural, hasil penelitian yang terkait dengan topik pekerjaan dan keluarga yang dilakukan dalam konteks tersebut mungkin saja tidak berlaku di negara non-western (termasuk di Indonesia). Sehingga tujuan dari penelitian ini adalah untuk menguji pengaruh dukungan supervisor yang suportif terhadap keluarga (family supporrtive supervisor behaviour/FSSB) terhadap tingkat konflik antara pekerjaan dan keluarga dalam konteks Indonesia. Populasi penelitian ini adalah tenaga pengajar (dosen) wanita (berkeluarga) di lingkungan Universitas Brawijaya, Malang. Konteks universitas/perguruan tinggi dipilih dengan alasan adanya peningkatan yang signifikan mengenai jumlah tenaga pengajar wanita di perguruan tinggi di Indonesia yang menyebabkan isu work family conflict merupakan salah satu isu yang penting di lingkungan perguruan tinggi di Indonesia. Disamping itu, tenaga pengajar di perguruan tinggi memiliki beban kerja yang relatif tinggi sehingga merupakan konteks yang relevan untuk meneliti work family conflict, namun penelitian dalam konteks ini masih terbatas.
\end{abstract}

Kata kunci: dukungan supervisor, keluarga pekerja, perempuan pekerja

\section{Abstract}

Empirical research in the field of work family conflict (conflict between work and family) showed that the work family conflict has a negative impact on individuals, families and organizations. Research on the effects of organizational support (work life balance policies and FSSB) to employees until now has been dominated by conducted research in the context of western countries. Due to the social and cultural differences, the results of research related to the topic of work and family done in the context of these may not apply in non-western countries (including Indonesia). Thus this study was aimed to examine the influence of supervisor support were supportive of the family (family supporrtive supervisor behavior / FSSB) to the level of conflict between work and family in the context of Indonesia. The population of the study was a lecturer (lecturers) woman (married) in Brawijaya University, Malang. Context universities / colleges been arguing for a significant increase of the number of female faculty members at universities in Indonesia led to the issue of work family conflict is one of the important issues in universities in Indonesia. In addition, a lecturer at the college have a relatively high workload so that is a relevant context to examine the work family conflict, but research in this context is limited.

Keywords: supervisor support, work family, women worker

\section{PENDAHULUAN}

Tenaga kerja wanita di Indonesia saat ini mengalami pertumbuhan yang sangat pesat. Menurut the World Bank (2013), Lebih dari 50\% tenaga kerja di Indonesia saat ini terdiri dari wanita dan beberapa diantaranya memegang peranan yang sangat penting di berbagai sektor. Sebagai contoh, sejumlah $18 \%$ posisi di parlemen nasional diduduki oleh wanita serta sedikitnya $20 \%$ posisi strategis di sektor pendidikan tinggi Indonesia dipegang oleh wanita [1]. Peningkatan yang signifikan dari partisipasi wanita di dalam

Alamat Korespondensi Penulis:

Wike, S.Sos, M.Si, DPA

Email : wikebangun@gmail.com

Alamat : J. Kebun Jeruk V/10A Malang tenaga kerja Indonesia merupakan salah satu konsekuensi dari perjuanagn kesetaraan gender bagi wanita Indonesia di bidang pendidikan (UN Women, 2012). Dengan pertumbuhan yang signifikan ini, jumlah keluarga dengan pendapatan ganda (suami istri bekerja)/ dual income earning households pun menjadi bertambah secara pesat [2]. Hal ini selanjutnya menyebabkan keseimbangan antara pekerjaan dan keluarga menjadi isu/bahasan yang penting di kalangan masyarakat Indonesia.

Penelitian empiris [3] [4] [5] di bidang work family conflict (konflik antara kerja dan keluarga) menunjukkan bahwa work family conflict memiliki dampak yang negatif terhadap individu, keluarga dan organisasi. Hal ini mendorong 
meningkatnya diskusi dan aksi di kalangan pengusaha dan pengambil keputusan publik terkait upaya untuk mengurangi atau menurunkan tingkat work family conflict di kalangan karyawan. Upaya tersebut diantaranya melalui pengembangan kebijakan keseimbangan antara pekerjaan dan keluarga (work life balance policies) serta melalui dukungan supervisor yang suportif terhadap keluarga (family supportive supervisor behaviour/ FSSB) yang bertujuan untuk membantu karyawan dalam mengelola/mengatur tuntutan perannya di pekerjaan sekaligus tuntutan peran keluarga.

Penelitian mengenai dampak dukungan organisasi (work life balance policies dan FSSB) terhadap karyawan sampai saat ini didominasi oleh penelitian di konteks Western countries. Sebaliknya, penelitian sejenis yang dilakukan di kontes non-Western Countries masih sangat terbatas [6] (Butss, Casper \& Yang, 2013). Disebabkan adanya perbedaan sosial dan kultural, hasil penelitian yang terkait dengan topik pekerjaan dan keluarga yang dilakukan dalam konteks Western countries mungkin saja tidak berlaku di negara non Western (termasuk di Indonesia). Oleh karena itu, penelitian yang terkait dengan topik pekerjaan dan keluarga yang dilakukan di konteks non-Western countries dirasa sangat penting untuk menjawab kesenjangan keilmuan (knowledge gap) ini. Sebagaimana yang ditegaskan oleh Handayani [7], aspek sosial dan kultural memiliki peranan yang sangat besar terhadap kemampuan individu untuk dapat mencapai keseimbangan antara kerja dan keluarganya.

\section{METODE PENELITIAN}

Metode pengambilan sampel dalam penelitian ini adalah probability sampling dengan jenis simple random sampling. Simpel random sampling merupakan teknik pengambilan samel anggota populasi dengan peluang yang sam, dilakukan secara acak tanpa memperhatikan strata dalam populasi.

\section{Metode Pengumpulan Data}

Data yang akan dipergunakan dalam penelitian ini adalah data primer yang akan diperoleh melalui survey kuesioner. Penelitian survey merupakan penelitian yang mempelajari relasional antar variabel dengan mengambil sampel dari satu populasi dan menggunakan angket sebagai alat pengumpul data yang utama [8]. Angket merupakan teknik pengumpulan data yang dilakukan dengan cara memberi seperangkat pertanyaan atau pernyataan tertulis kepada responden untuk dijawab [9].

\section{HASIL DAN PEMBAHASAN}

\section{A.1 Uji Validitas}

Pengujian validitas dilakukan untuk mengetahui apakah alat ukur atau instrumen yang digunakan dalam penelitian ini sudah tepat, yaitu mampu mengukur apa yang akan diukur dalam penelitian. Pengujian seluruh konstruk ini disebabkan adanya perbedaan responden, waktu, dan lokasi penelitian [10].

Dalam penelitian ini, perhitungan dilakukan dengan mengkorelasi setiap skor item dengan skor total dengan menggunakan teknik korelasi Bivariate Pearson menggunakan SPSS. Data dikatakan valid apabila nilai koefisien validitas lebih dari 0.1864 . Hasil pengujian validitas dapat dilihat pada tabel 4.1.

Tabel 4.1.

Hasil Uji Validitas Instrumen Penelitian Variabel Butir Pertanyaan Koefisien Validitas Nilai Signifikansi Keterangan

\begin{tabular}{|c|c|c|c|c|}
\hline Variabel & $\begin{array}{c}\text { Butir } \\
\text { Pertan } \\
\text { yaan }\end{array}$ & $\begin{array}{l}\text { Koefisien } \\
\text { Validitas }\end{array}$ & $\begin{array}{c}\text { Nilai } \\
\text { Signifikansi }\end{array}$ & $\begin{array}{c}\text { Keteran } \\
\text { gan }\end{array}$ \\
\hline \multirow{14}{*}{ FSSB } & P1 & 0.582 & o.ouo & valid \\
\hline & PZ & 0.525 & a.ono & valid \\
\hline & P3 & 0.640 & o.ono & valid \\
\hline & P4 & 0.806 & o.ono & valid \\
\hline & P5 & 0.763 & o.ono & valid \\
\hline & PG & 0.768 & o.000 & valid \\
\hline & P7 & 0.829 & Qouo & valid \\
\hline & Pg & 0.800 & o.ono & valid \\
\hline & pg & 0.815 & o.ono & valid \\
\hline & P10 & 0.771 & o.ouo & valid \\
\hline & P11 & 0.664 & 0.000 & Valid \\
\hline & P12 & 0.524 & o.ono & valid \\
\hline & P13 & 0.656 & o.ouo & valid \\
\hline & P14 & 0.815 & o.ouo & valid \\
\hline \multirow{5}{*}{$\begin{array}{l}\text { Work } \\
\text { Faminy } \\
\text { Conffinct }\end{array}$} & P15 & 0.753 & a.oue & valid \\
\hline & P16 & 0.852 & o.ono & valid \\
\hline & P17 & 0.861 & 0.000 & valid \\
\hline & P18 & 0.836 & 0.000 & valid \\
\hline & P19 & 0.763 & o.ono & valid \\
\hline
\end{tabular}

Berdasarkan hasil uji validitas instrumen penelitian pada tabel 4.1.dapat diketahui bahwa seluruh butir pertanyaan variabel

FSSBdan Work Family Conflict memiliki nilai koefisien validitas lebih dari 0.1864 dan nilai 
signifikansi kurang dari nilai $\alpha(0.05)$ sehingga dapat disimpulkan untuk setiap variabel pertanyaan tersebut adalah valid.

A.2 Uji Reliabilitas

Uji Reliabilitas digunakan untuk mengetahui konsistensi dari butir pertanyaan kuisioner sebagai alat ukur, sehingga suatu pengukuran dapat dipercaya. Reliabilitas adalah karakteristik pengukuran yang dikaitkan dengan akurasi, presisi dan konsistensi [11]. Pengujian menggunakan Alpha Cronbach, jika koefisien alpha lebih dari 0.7 maka data Reliable, jika koefisien alpha kurang dari 0.7 maka data tidak Reliable.Hasil pengujian relibialitas instrumen dapat dilihat pada tabel 4.2.

Table 4.2.

Hasil Uji Reliabilitas Kuisioner

\begin{tabular}{|c|c|}
\hline Koefisien Alpha Cronbach & Keterangan \\
\hline 0.846 & Reliabel \\
\hline
\end{tabular}

Berdasarkan hasil uji reliabilitas pada tabel 4.2 diketahui bahwa seluruh butir pertanyaan variabel Supervisor Supportdan Work Family Conflict mempunyai nilai koefisien Alpha Cronbach lebih dari 0.7, sehingga dapat disimpulkan bahwa semua variabel tersebut sudah reliabel (handal).

Sesuai hasil uji validitas dan reliabilitas, diketahui kuisioner yang digunakan sudah valid dan reliabel, artinya alat pengumpulan data sudah layak untuk digunakan, maka data yang terkumpul dapat dilakukan analisis lebih lanjut.

\section{B. Statistika Deskriptif}

B.1 Statistika Deskriftif dari Perbandingan Persentase Unit Kerja Responden

\begin{tabular}{|c|c|c|}
\hline Unit Kerja & (14\% & 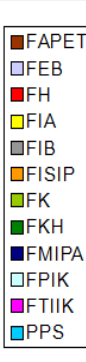 \\
\hline
\end{tabular}

Gambar 4.1. Persentase Unit Kerja Responden

Berdasarkan diagram lingkaran tersebut diketahui perbandingan dalam persentase unit kerja dari responden dan dapat disimpulkan bahwa 3\% responden berasal dari Fakultas Peternakan (FAPET), 4\% responden berasal dari Fakultas Ekonomi dan Bisnis (FEB), 14\% responden berasal dari Fakultas Hukum (FH),
14\% responden berasal dari Fakultas IImu Administrasi (FIA), 3\% responden berasal dari Fakultas IImu Budaya (FIB), 1\% responden berasal dari Fakultas IImu Sosial dan IImu Politik (FISIP), $18 \%$ responden berasal dari Fakultas Kedokteran (FK), 4\% responden berasal dari Fakultas Kedokteran Hewan (FKH), 16\% responden berasal dari Fakultas Matematika dan IImu Pengetahuan Alam (FMIPA), 14\% responden berasal dari Fakultas Perikanan dan IImu Kelautan (FPIK), 6\% responden berasal dari Fakultas Teknologi Informasi dan Komunikasi (FTIIK) dan 3\% responden berasal dari Program Pasca Sarjana (PPS).

B.2 Statistika Deskriftif dari Perbandingan Persentase Jabatan / Profesi Responden

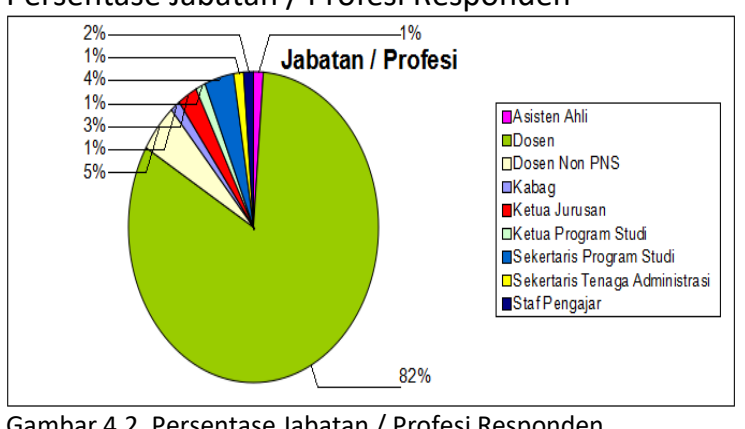

Berdasarkan diagram lingkaran tersebut diketahui perbandingan dalam persentase jabatan / profesi dari responden dan dapat disimpulkan bahwa $1 \%$ responden berprofesi sebagai asisten ahli, $82 \%$ responden berprofesi sebaga dosen, $5 \%$ responden berprofesi sebagai dosen non PNS, $1 \%$ responden berprofesi sebagai kabag, 3\% responden berprofesi sebagai ketua jurusan, $1 \%$ responden berprofesi sebagai ketua program studi, $4 \%$ responden berprofesi sebagai sekertaris program studi, $1 \%$ responden berprofesi sebagai sekertaris tenaga administrasi dan $2 \%$ responden berprofesi sebagai staf pengajar.

B.3 Statistika Deskriftif dari Perbandingan Persentase Usia Responden

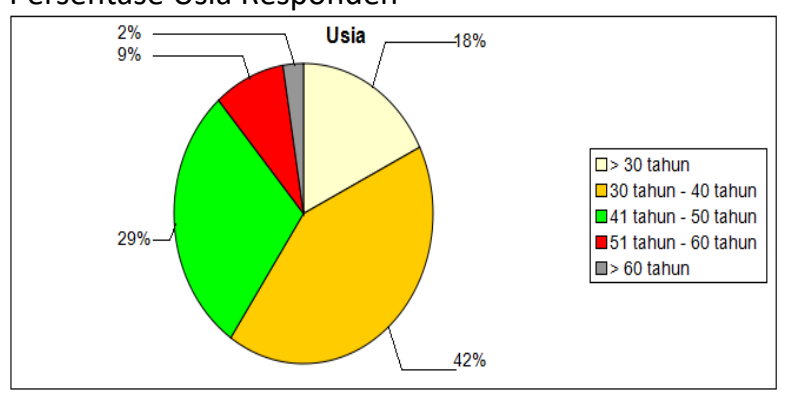

Gambar 4.3. Persentase Usia Responden 
Berdasarkan diagram lingkaran tersebut diketahui perbandingan dalam persentase usia dari responden dan dapat disimpulkan bahwa $18 \%$ responden berusia kurang dari 30 tahun, $42 \%$ responden berusia antara 30 sampai 40 tahun, 29\% responden berusia antara 41 sampai 50 tahun, 9\% responden berusia antara 51 sampai 60 tahun dan $2 \%$ responden berusia lebih dari 60 tahun.

B.4 Statistika Deskriftif dari Perbandingan Persentase Status Pernikahan Responden

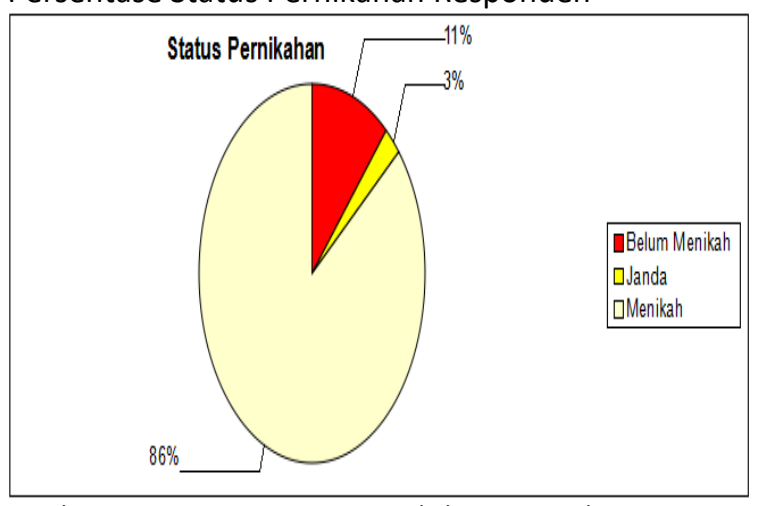

Gambar 4.4. Persentase Status Pernikahan Responden

Berdasarkan diagram lingkaran tersebut diketahui perbandingan dalam persentase status pernikahan dari responden dan dapat disimpulkan bahwa $11 \%$ responden berstatus belum menikah, 3\% responden berstatus janda dan $86 \%$ berstatus menikah.

B.5 Statistika Deskriftif dari Perbandingan Persentase Jumlah Anak Responden

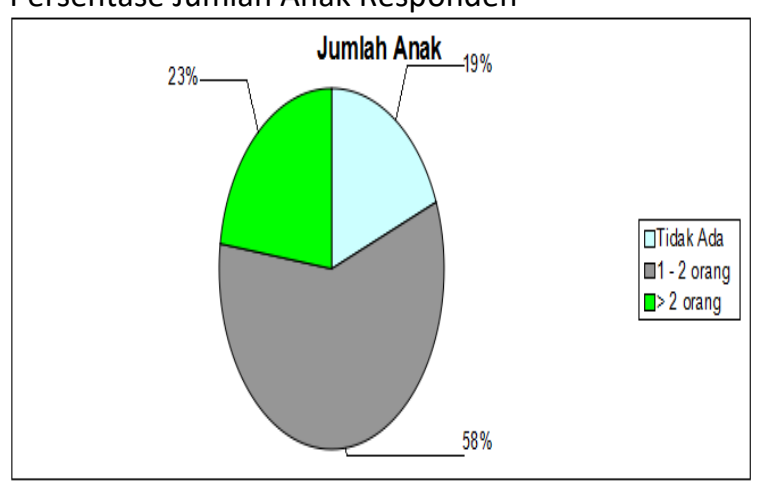

Gambar 4.5. Persentase Jumlah Anak Responden

Berdasarkan diagram lingkaran tersebut diketahui perbandingan dalam persentase jumlah anak yang dimiliki oleh responden dan dapat disimpulkan bahwa $19 \%$ responden belum mempunyai anak, 58\% responden memiliki anak antara 1 sampai 2 orang dan 23\% responden memiliki anak lebih dari 2 orang.
B.6 Statistika Deskriftif dari Perbandingan Persentase Kepemilikan Pembantu Rumah Tangga Responden

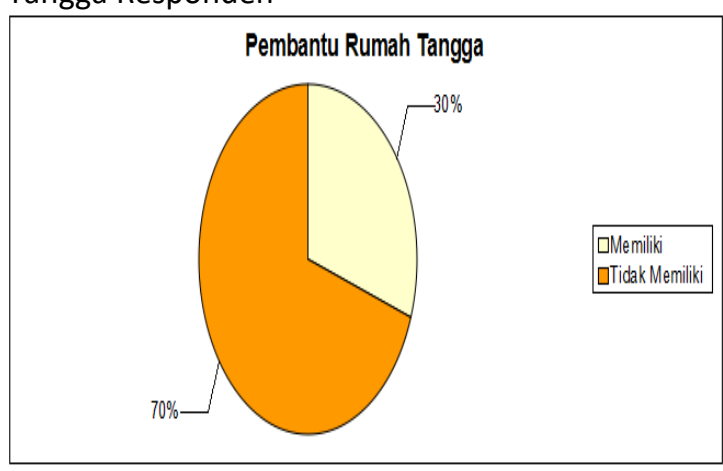

Gambar 4.6. Persentase Pembantu Rumah Tangga Responden

Berdasarkan diagram lingkaran tersebut diketahui perbandingan dalam persentase kepemilikan pembanturumah tangga oleh responden dan dapat disimpulkan bahwa $30 \%$ responden memiliki pembantu rumah tangga dan 70\% responden tidak memiliki pembantu rumah tangga.

\section{B.7 Mean, Standar Deviasi dan Korelasi}

Tabel 4.3. Mean, Standar Deviasi dan Korelasi

Dari tabel 4.3 dapat diketahui bahwa kecuali variabel kepemilikan pembantu rumah tangga (PRT), seluruh variabel penelitian ini memiliki standar deviasi yang tidak tinggi karena tidak melebihi nilai rata-rata (mean). Semakin besar nilai standar deviasi berarti semakin tinggi penyimpangan data dengan nilai rata-ratanya. Sebaliknya, semakin kecil nilai standar deviasi berarti data berkelompok di sekitar nilai rataratanya dan tidak menunjukkan variasi yang banya [12].

Korelasi antar variabelmemiliki nilai yang bervariasi antara 0.015 sampai dengan 0.446 . Nilai korelasi tersebut menunjukkan bahwa seluruh variabel penelitian tidak menunjukkan adanya masalah multikolinearitas karena rule of thumb nilai korelasi yang melebihi 0.8 dapat menjadi indikasi adanya multikolinearitas.

\section{KESIMPULAN}

Sebagaimana yang telah ditegaskan oleh Straub [13], bagian latar belakang penelitian ini mengidentifikasi bahwa penelitian yang menginvestigasi hubungan/pengaruh dukungan supervisor (dalam bentuk family supportive supervisor behavior/FSSB) terhadap karyawan masih sangat terbatas. Hal ini salah satunya disebabkan oleh konsep dan instrumen 
pengukuran FSSB baru saja dikembangkan pada tahun 2009. Terkait dengan hal ini, penelitian ini bertujuan untuk menginvestigasi hubungan/pengaruh antara FSSB terhadap konflik antara pekerjaan dan keluarga (work family conflict/WFC), khususnya dalam perspektif karyawan wanita (yaitu dosen wanita pada Universitas Brawijaya). Hasil penelitian ini mengkonfirmasi pandangan dalam literatur yang menyatakan bahwa FSSB memiliki pengaruh yamg signifikan untuk mengurangi tingkat work family conflict karyawan. Dengan kata lain, dukungan supervisor merupakan hal yang penting untuk diberikan kepada karyawan/bawahan sebagai salah satu upaya untuk membantu karyawan tersebut agar lebih mampu mengelola konflik antara pekerjaan dan keluarga yang dihadapinya.

\section{SARAN}

Penelitian ini memiliki beberapa keterbatasan, salah satunya adalah penggunaan kuesioner yang terstruktur membatasi scope dari penelitian ini. Keterbatasan ini terkait dengan kedalaman data yang dikumpulkan. Namun, keterbatasan ini dapat dipertanggungjawabkan karena hipotesis penelitian ini lebih menekankan pada jawabah terhadap hipotesis, daripada kedalaman bahasan. Disisi lain, melanjutkan studi ini dengan pendekatan kualitatif untuk melihat perspektif mendalam berdasarkan pengalaman dari dosen perempuan menjadi rekomendasi penelitian ini.

\section{UCAPAN TERIMA KASIH}

Terima kasih kami sampaikan pada Program Kajian Wanita - Pascasarjana, Universitas Brawijaya Malang yang telah membantu secara finansial kegiatan penelitian ini.

\section{DAFTAR PUSTAKA}

[1].UN Women, 2012. Women are integral part of Indonesian success Retrieved 15/08, 2013, from http://www.unwomen.org/en/news/stories/ 2012/12/women-are-integral-part-ofindonesian-success

[2].Ridho, S. L. Z., \& Al Raysid, M. N. (2010). Partisipasi angkatan kerja perempuan dan rasio jenis kelamin: Studi kasus negara anggota ASEAN Retrieved 27/02/2013, from http://www.bappenas.go.id/blog/?p=297

[3]. Frone, MR (2000). Interpersonal Conflict at Work and Physcological Outcomes: testing a model among young workers. Journal of
Occupational Health Physchology, April, Vol. 5(2), pp. 246-55.

[4].Frone, M. R., Russell, M., \& Cooper, M. L. (1997). Relation of work-family conflict to health outcomes: A four-year longitudinal study of employed parents. Journal of Occupational and Organizational Psychology, 70(4), 325-335

[5]. Galovan, et al. (2010). The work - Family interface in the Development and Psychopatology, No. 18, pp. 253-73.

[6].Butts, M. M., Casper, W. J., \& Yang, T. S. (2013). How important are work-family support policies? A meta-analytic investigation of their effects on employee outcomes. Journal of Applied Psychology, 98(1), 1-25.

[7]. Handayani (2013). Keseimbangan Kerja Keluarga pada Perempuan Bekerja: Tinjauan Teori Border. Buletin Psikologi Vol. 21 (2), pp. 90-101.

[8].Singarimbun, Effendy (1995). Metode Penelitian Survei. Jakarta: LP3ES

[9].Sugiyono (2010). Metode Penelitian Kuantitatif, Kualitatif \& RND. Bandung: Alfabeta

[10]. Cooper, D., Schindler, P.S. (2001). Business Research Method (6 $6^{\text {th }}$ Ed.), New York: McGraw-Hill

[11]. Cooper, D., Schindler, P.S. (2002). Business Research Method (7 $7^{\text {th }}$ Ed.), New York: McGraw-Hil

[12]. Riduwan \& Kuncoro (2012). Cara menggunakan dan Memaknai Path analysis (Analisis Jalur). Bandung: Alfabeta.

[13]. Straub, C. (2012). Antecedents and organizational consequences of family supportive supevisor behavior: A multilevel conceptual framework for research. Human Resource Management Review, 22, 15-26. 